\title{
A Ciência da Comunicação e a Comunicação da Ciência: Um Dossiê de Interfaces
}

Myrian DEL VECCHIO DE LIMA

Eloisa Belling LOOSE ${ }^{2}$

Como pesquisadoras que têm incluídos no rol de suas reflexões e investigações a grande questão das interfaces entre Comunicação e Ciência, partilhamos, com inúmeros estudiosos da área, o pressuposto de que os meios de comunicação desempenham função fundamental na democratização do saber ao popularizar a ciência. Não apenas tais meios são essenciais, mas todas as formas de comunicação que divulguem, de maneira objetiva, clara, motivadora, atraente e competente, princípios e valores, métodos e técnicas, novidades e características, políticas e reflexões sobre o fazer científico e seus produtos.

A revista AçãoMidiática, do Programa de Pós-Graduação em Comunicação (PPGCom), da Universidade Federal do Paraná, é uma publicação que divulga textos produzidos por aqueles que estudam, pensam, refletem, pesquisam e produzem intelectualmente sobre a Ciência da Comunicação. Esta edição, a sétima, além de realizar essa tarefa, detém-se em um aspecto abrangente: como essa Comunicação, como ciência, por meio de suas visões epistemológicas, e como campo de práticas, por meio de suas técnicas profissionais, divulga a própria Ciência de maneira geral?

E vai além: o objeto Ciência, como produto de conhecimento em permanente processo de acumulação de informações e de evolução de teorias e metodologias, pode, e deve, ser divulgado pela Comunicação de maneiras as mais diversas, atendendo, assim, de forma mais eficiente, e, por que não, interessante e criativa, os mais diferentes públicos.

Este dossiê sobre Comunicação e Ciência apresenta uma variedade de textos, nos quais essa relação de interface é examinada e posta em relação com públicos, canais, emissores-receptores, conteúdos etc. São textos produzidos pelos que podem ser considerados, atualmente, grandes expoentes na área no Brasil, convidados e apresentados especialmente para esta edição.

A visão mais epistemológica está excelentemente registrada nas respostas do professor Isaac Epstein, um dos maiores especialistas em filosofia da ciência e suas relações com a comunicação do país, em entrevista especial para AçãoMidiática, que permite revisões e novos olhares sobre o tema

1 Jornalista. Doutora em Meio Ambiente e Desenvolvimento pela Universidade Federal do Paraná (UFPR). Mestre em Comunicação Social pela Universidade Metodista de São Paulo (Umesp). Professora do Programa de Pós-Graduação em Meio Ambiente e Desenvolvimento (PPGMade) e do Programa de Pós-Graduação em Comunicação (PPGCom) da UFPR. Coordenadora do grupo de pesquisa Interfaces: Comunicação, Educação e Meio Ambiente. Email: myriandel@gmail.com

2 Jornalista. Doutoranda do Programa de Pós-Graduação em Meio Ambiente e Desenvolvimento (PPGMade) da Universidade Federal do Paraná (UFPR). Mestre em Comunicação pela Universidade Federal do Rio Grande do Sul (UFRGS). Bolsista CNPq. Integrante do grupo de pesquisa Interfaces: Comunicação, Educação e Meio Ambiente. 
e o coloca em um patamar de importância entre as grandes temáticas de pesquisa em Comunicação.

Os quatro artigos que abrem a edição são assinados pelos convidados a integrar este dossiê - Wilson da Costa Bueno, Graça Caldas, Isaltina Maria de Azevedo Mello Gomes e Maria das Graças Targino - , nomes que têm mantido uma construção de pesquisa permanente sobre essa temática de interface, em suas universidades, contribuindo para a consolidação da bibliografia nacional na área - as três últimas têm como coautoras as parceiras de pós-graduação Kátia Zanvettor, Natália Flores e Názia Holanda Torres, respectivamente.

Os dois primeiros artigos são resultado de uma pesquisa quantitativa extensa: Wilson $d a$ Costa Bueno (USP e Umesp) busca saber como os portais das universidades brasileiras deixam de cumprir sua função de dar visibilidade à própria produção científica - uma vez que deveriam funcionar como vitrines da divulgação da ciência ali desenvolvida - comprometendo, assim, a democratização e o partilhamento social do conhecimento científico nacional; já Graça Caldas e Kátia Zanvettor (Unicamp) verificam como está o estado da arte da pesquisa em divulgação científica no país, mostrando os resultados iniciais do projeto "Divulgação Científica e Sociedade: Memória e Estado da Arte" (Labjor/Unicamp), a partir de um mapeamento no banco de teses da Capes. Em uma linha de pesquisa mais qualitativa, Isaltina Maria de Azevedo Mello Gomes e Natália Flores (UFPE) abordam a construção do público de divulgação científica no âmbito de uma cultura participativa, aquela dos blogs na Internet e de outras mídias sociais; enquanto Maria das Graças Targino e Názia Holanda Torres (UFPB) enfocam um dos pontos-chave da discussão na área: a importância do fluxo informacional sobre ciência que chega às coletividades em geral, indo além da comunidade dos pesquisadores, de forma a alfabetizar cientificamente a população, permitindo práticas cidadãs.

Complementam o dossiê mais quatro textos apresentados à avaliação, que trazem aspectos diversos e interessantes da divulgação científica. O de Diego Salcedo (UFPE) explora um objeto bastante original: os selos postais como possibilidade de veiculação de imagens científicas que representam discursos que informam, comunicam e interpelam indivíduos e comunidades, incluindo-se como meios de comunicação na divulgação da ciência. Já Felipe da Costa, Valquíria Michela John e Jamile Tonini (Univali), em pesquisa bibliográfica e documental, analisam artigos de dez Encontros Nacionais da Sociedade Brasileira de Pesquisadores em Jornalismo (SBPJor) sobre os temas jornalismo científico, ambiental e de saúde, apontando ênfases de área, procedimentos metodológicos e objetos de pesquisa. Fabricio José Mazocco e Thales Haddad Novaes de Andrade (UFSCar), ao considerarem a patente como instrumento de divulgação científica, apontam os requisitos necessários para sua proteção, seu dimensionamento e o estabelecimento de uma relação dessa fonte de informação tecnológica com os critérios de noticiabilidade. Em formato ensaístico, Jorge Kanehide Ijuim (UFSC), com base em pesquisa realizada na Universidade de Coimbra, traz apontamentos reflexivos para a compreensão do pensamento do sociólogo português Boaventura de Sousa Santos sobre o pensamento científico contemporâneo, de forma a contribuir para a 
construção de uma crítica dos modelos de jornalismo atual.

Além do dossiê, complementam esta edição mais seis artigos que contemplam temáticas variadas, sendo três deles de origem nacional e três de origem internacional (latino-americana). Pela ordem, dois artigos inseridos no contexto político-eleitoral e assinados por pesquisadores do México: Daniela Cerva Cerna e Carlos Eduardo Cornejo Ballesteros (UAM) empregam a análise do conteúdo para examinar a agenda de gênero em campanhas e plataformas políticas dos principais candidatos nas eleições presidenciais de 2012 no México, em busca de definições ou de compromissos para o reconhecimento de uma ampliação dos direitos das mulheres e igualdade de gênero no país. Já o texto de Braulio González Vidaña (UAM) estuda as percepções dos jovens mexicanos sobre a política, por meio da análise dos resultados do Índice Nacional de Participação da Juventude no México, e sua utilidade para o desenho de estratégias de comunicação política por parte dos partidos que integram o processo eleitoral. Os artigos vindos do México são complementados pelo trabalho de Angélica Mendieta Ramírez (BUAP) que, por meio dos resultados da base de dados Latinobarómetro 2013, examina as linhas de ação para reforçar a confiança dos cidadãos da região nas instituições e nos procedimentos políticos da democracia.

Os três artigos nacionais sobre temas diversos aparecem nesta ordem: Wesley Pereira Grijó (UFRGS) estuda a telenovela "Lado a lado" (2012), da Rede Globo, para identificar se ocorrem avanços na representação dos negros no contexto da ficção televisiva nacional; Ana Luiza Coiro Moraes, Alisson Machado e Tainan Pauli Tomazetti (UFSM) investigam as relações entre o campo científico e o jornalístico televisivo, tendo como pano de fundo as manifestações de rua ocorridas no Brasil em junho de 2013, quando muitas das fontes consultadas pela Globo News para entender o processo foram os intelectuais; ainda no campo televisivo, o texto de Paulo Eduardo Silva Lins Cajazeira (UFCA) procura compreender as novas relações comunicacionais do telejornal, em convergência com as redes sociais na Internet, que geram novas formas de participação da audiência.

No fechamento da edição, publica-se resenha, de autoria de Humberto da Cunha Alves de Souza (UFPR), do livro "A Cultura no Mundo Líquido Moderno”, do sociólogo polonês, radicado na Inglaterra, Zygmunt Bauman, que ganhou repercussão intelectual mundial com suas perspectivas de uma pós-modernidade que ele denomina de "líquida" e na qual os indivíduos passam de produtores a consumidores. A resenha dirige seu entendimento para uma perspectiva culturalista nos estudos de comunicação.

Boa leitura a todos!

\section{Referências}

EPSTEIN, Isaac. Divulgação Científica: 96 verbetes. Campinas, SP: Pontes, 2002. 